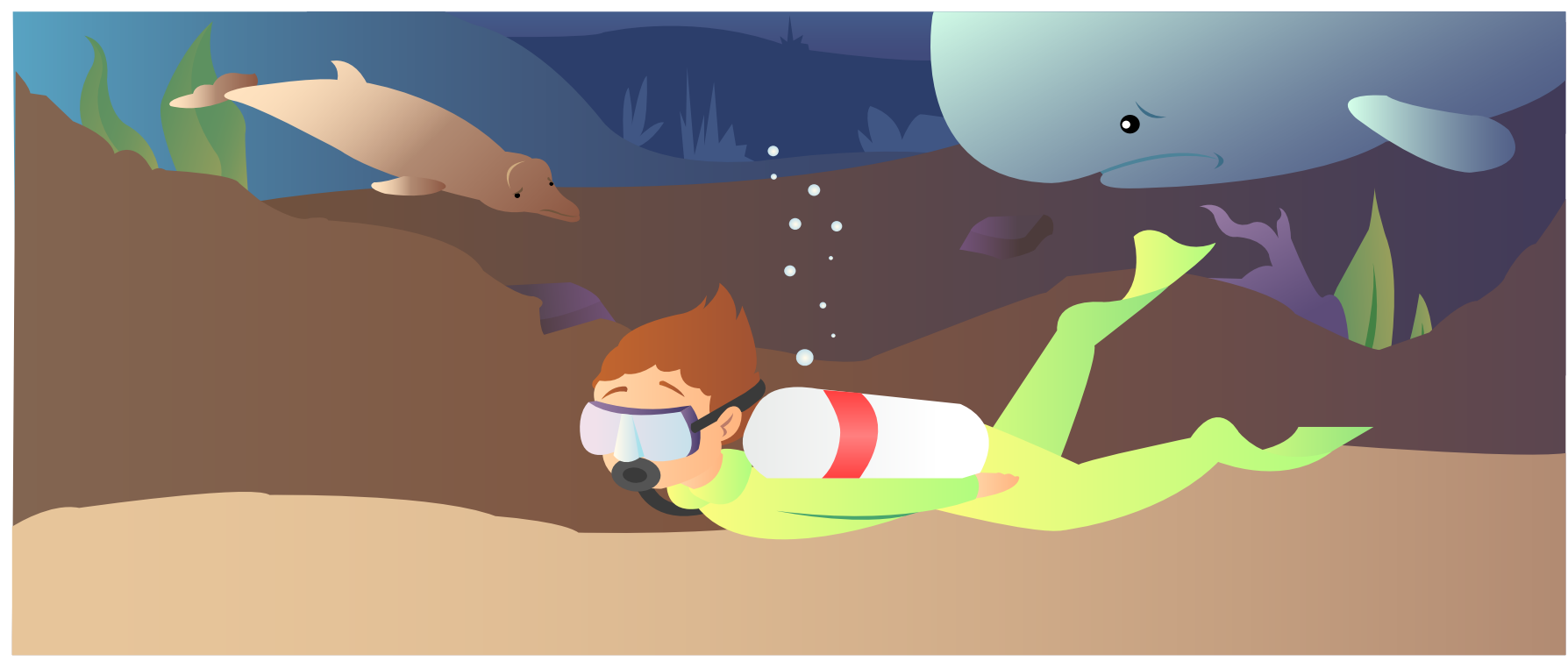

\title{
HUMAN DISTURBANCES MIGHT CAUSE DANGEROUS GAS BUBBLES TO FORM IN DEEP-DIVING WHALES
}

\section{Andreas Fahlman ${ }^{1 *}$, Peter Lloyd Tyack ${ }^{2}$, Patrick James O’Malley Miller ${ }^{2}$ and Petter H. Kvadsheim ${ }^{3}$}

${ }^{1}$ Fundación Oceanogràfic de la Comunidad Valenciana, Valencia, Spain, ${ }^{2}$ Sea Mammal Research Unit, University of St. Andrews, St. Andrews, United Kingdom, ${ }^{3}$ Norwegian Defence Research Establishment (FFI), Maritime Systems Division, Horten, Norway

\section{REVIEWED BY: \\ NADYA \\ AGE: 12 \\ CAROLYN \\ AGE: 12}

Over millions of years, whales have evolved for diving in the ocean to obtain food while holding their breath. Because whales are air-breathing mammals, they eventually have to return to the ocean surface to get more oxygen. However, the air in the lungs also contains nitrogen, a gas that is taken up but not used by the body. As the whale dives deeper, the pressure from the water increases and more nitrogen is taken up by blood circulating from the lungs to other tissues. When the whale returns to the surface and the water pressure decreases, the nitrogen gas is returned to the lungs. If the whale spends too much time in the zone where nitrogen is taken up at elevated pressure, bubbles may form when the whale returns to the surface; similar to what happens when you open a soda bottle. The bubbles can cause many different problems inside the whale's body and even cause death. Whales normally do not experience problems caused by bubbles. In recent years, scientists have discovered that when humans disturb whales, their dive behavior or their bodily functions may change in ways that increase the risk of formation of bubbles that could cause 


\section{HYPOXIA}

Low levels of oxygen.

\section{FIGURE 1}

What do whales and soda bottles have in common? The drawing shows two whales with gas bubbles inside the body. When the whales are disturbed during diving, the whales take up more nitrogen gas. The gas comes out as bubbles as the whale returns to the surface and the pressure is released, similar to the bubbles formed when you open a soda bottle. Credits for drawing Anastasia Fahlman. problems and death. A better understanding of whale behavior and how the nitrogen bubbles form may help scientist develop tools that can prevent these problems in whales.

\section{WHAT DO WHALES AND SODA BOTTLES HAVE IN COMMON?}

When you open a soda bottle you can see bubbles forming, and if you shake the bottle before opening it, the liquid comes rushing out. Bubbles can also form inside diving whales and cause a problem known as decompression sickness [1]. In both the soda bottle and the diving whales, the bubbles form from gas that has dissolved because of the increasing pressure; as the soda bottle is opened and as the whale returns to the surface to breathe, the pressure decreases, which causes the bubbles to form.

The bubbles in the soda provide the fizzy taste of the drink, which is nice, but bubbles may cause problems if they form inside a whale (Figure 1). For example, if the bubble is in a blood vessel, it might block blood flow and prevent oxygen delivery to the tissues. In this case, the tissues become hypoxic, a fancy word for a situation in which the oxygen level is too low. Because oxygen is important to convert food into energy, mammals cannot live without oxygen, and the hypoxia may cause the tissue to die. If bubbles form in the heart or in the nervous system, this may kill the whale.

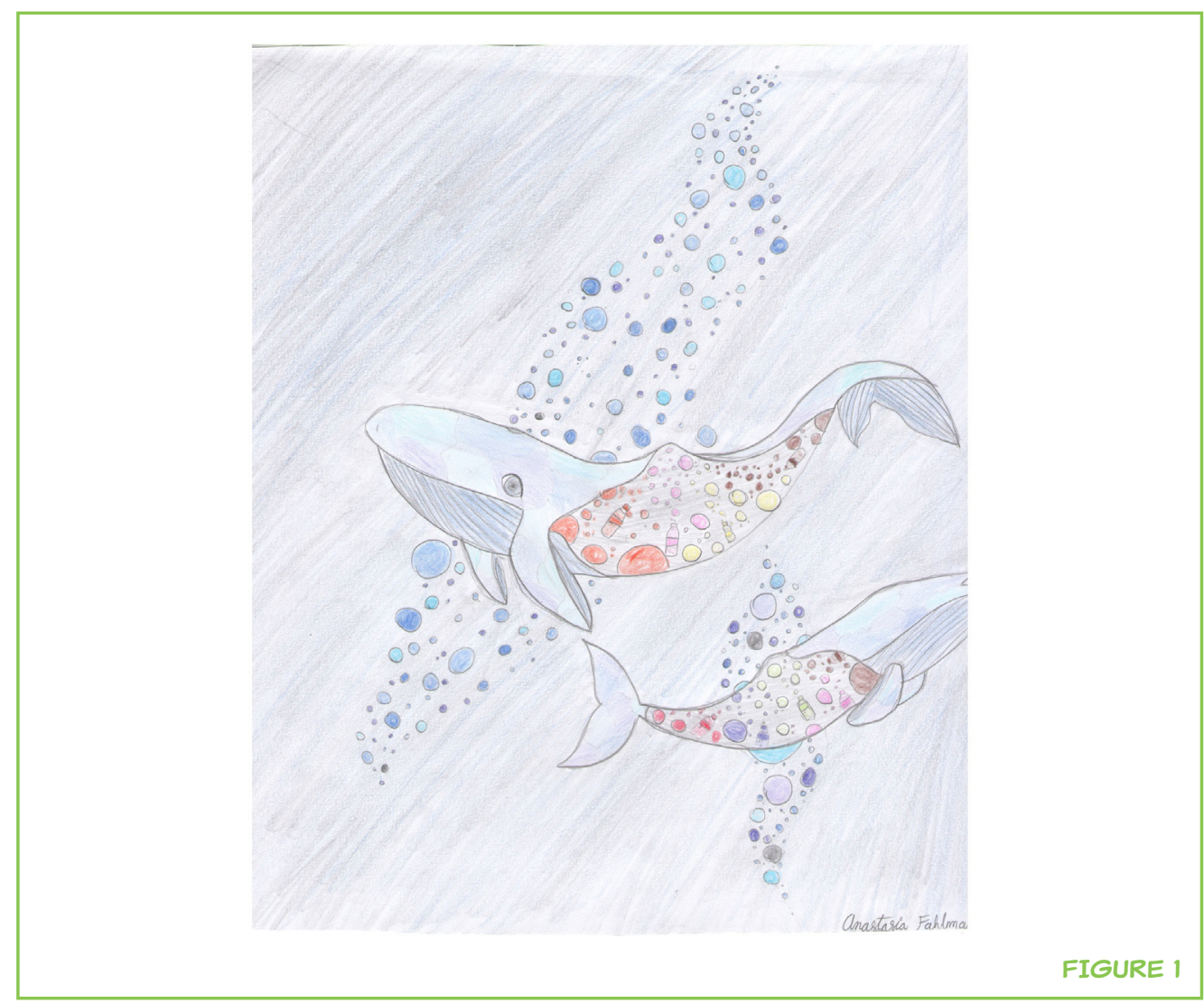




\section{ADAPTATION}

Changes in a species physiology or anatomy over many generations caused by genetic changes leading to a better chance for that individual to survive.

CIRCULATORY (CARDIOVASCULAR) SYSTEM

Heart, and blood vessels (arteries and veins).

Whales and other marine mammals have several physiological and anatomical adaptations that help minimize the risk of bubbles forming after a dive. However, there may be some unusual man-made situations in which these adaptations do not work as they should $[2,3]$. During normal diving, gases such as oxygen and nitrogen pass from the lungs to the blood and these gases are delivered throughout the body by the circulatory system (heart and blood vessels). When the whale descends on a dive, the pressure from the surrounding water increases as the whale goes deeper, compressing the chest of the whale, and increasing the pressure in the lungs. The amount of gas dissolved in a liquid (blood in this case) increases with increasing pressure, so the increasing pressure in the lungs increases the amount of gas that gets into the blood and then circulates throughout the whale's body. You can try this with a soda bottle or can (this does not work in a glass bottle), or sparkling water if you want a healthy alternative, and do the following experiment: Ask your friend, mom, or dad to shake the can and then tell them to open it without spilling the liquid. Shaking the bottle disturbs the gas (in this case carbon dioxide) and when the bottle is opened, the gas rapidly comes out of the liquid as the pressure is reduced, forcing the liquid to squirt out of the bottle. What you can do to prevent the liquid from squirting out is to squeeze the bottle hard for about 2 min before opening it. As you squeeze the bottle, the pressure inside increases, which puts the gas back into the liquid, and you can then open the bottle without the liquid shooting out.

\section{HOW CAN WHALES HOLD THEIR BREATH FOR MORE THAN 2 H?}

Let's get back to the whale. The majority of the gas in the lungs is nitrogen. The body does not use nitrogen, but it is the main gas present in the air we (and whales) breathe. When the whale dives, the increased pressure in the lungs increases the amount of gas taken up by the blood and delivered to tissues. The amount of nitrogen dissolved in the blood and tissues increases due to the increased pressure. Some of the nitrogen gas taken up during each dive is removed when the whale exhales at the surface, but if the time at the surface is not long enough, and if the whale does not breathe enough times, not all the excess nitrogen is removed.

Whales and other marine mammals that dive to obtain food underwater often dive in bouts. The bouts are periods when the whale dives repeatedly, with only a short amount of time at the surface before the next dive. We think that marine mammals dive in bouts to get as much food as possible while they are diving. For example, if they find a large school of fish, they do not want to spend so much time at the surface that the school escapes, so they dive again to quickly get down to catch more fish. Therefore, they only stay at the surface long enough to replenish their oxygen. However, the time at the surface may not be long enough to remove all the nitrogen from their blood. Because of 


\section{PHYSIOLOGY}

The study of how animals function.

RESPIRATORY SYSTEM

Lung and airways (trachea, bronchi, and bronchioles). this, the amount of nitrogen increases slowly from dive to dive, and sometimes it increases enough that bubbles may form in the whales when they return to the surface.

As whales evolved over millions of years, they developed strategies to avoid nitrogen building up to dangerous levels. For example, there are often long periods of time between diving bouts when the whales stay near the surface. These long periods may serve to remove the excess nitrogen from the whales' blood, reducing it to safe levels. Another strategy used by many marine mammals is to reduce the speed at which they return to the surface-when they are at a depth of about 30-40 $\mathrm{m}$ they slow down. Scientists think that slowing down helps to reduce the chance that bubbles will form, similar to slowly opening the soda bottle after it has been shaken as compared with opening it rapidly.

There are also physiological strategies to reduce the risk that bubbles form. Physiology is the study of how an animal's body functions, and some scientists who study physiology are interested in how certain animals have solved different environmental challenges. For example, what strategies allow animals to survive in very hot or very cold climates, or what are the differences between how fish gills and the lungs of other animals are used to exchange gases? Physiologists studying whales are interested in how these animals can hold their breath for over $2 \mathrm{~h}$, and how they can dive very deep, almost $3 \mathrm{~km}$ down into the ocean, where the pressure is 300 times higher than at the surface.

Physiologists are also interested in understanding how whales reduce the risk of bubbles forming and these scientists have suggested that the unusual respiratory system, with a very flexible chest and rigid upper airways, of whales may help reduce how much nitrogen is taken up. When the whale dives, the increasing pressure causes the lungs and chest to compress. Humans have a chest that withstands the pressure during diving, but diving marine mammals have an unusually soft chest, and when they dive deep the lungs simply collapse like an empty balloon. Lung collapse would likely kill a human, but the whales do it several times every day. When the lungs are collapsed there is no more gas available that can get into the blood and cause problems when the whale returns to the surface. During the ascent the lungs reinflate so that the whale can breathe normally when it reaches the surface.

In addition, whales have evolved another trick called the dive response. Humans, and particularly babies, also have this response, but whales are much better at it. The dive response is a set of cardiovascular (a fancy word for both the heart and the blood vessels), changes, in which the heart rate is reduced to just a few beats per minute. During the dive response, there is still some blood flow to organs, such as the heart and brain, which cannot survive without oxygen. So, when a whale dives it turns into a heart-brain machine, in which the blood is directed to the brain and heart while little or no blood is directed to the other organs, which can manage better without oxygen. The dive response helps to 


\section{DIVE BOUTS}

A series of repeated dives, often when the whale is hunting for prey, interrupted by a short surface interval.

ATMOSPHERE ABSOLUTE

A unit of pressure.

\section{FORAGING}

Hunting for food.

GAS SOLUBILITY

The amount of gas that can exist in a liquid. conserve, or save, the available oxygen and extend the length of time that the whale can hold its breath. The dive response also helps minimize the amount of nitrogen that is taken up by other tissues and therefore helps to reduce the chances that bubbles form when the whale comes back to the surface.

\section{A COMPLICATED LIFE IN THE DARK!}

As you can see, diving mammals live a difficult life. Not only do they have to find food underwater in a cold and dark world, they also only have a limited time available to find and catch the rapidly moving prey. If less food is available, they have to make more dives to obtain enough food to survive, which mean that the dive bouts are longer, possibly increasing the amount of nitrogen that dissolves in the blood and therefore the risk that bubbles will form. This means that sometimes whales have to push the limits of what they can do, and it is possible that certain man-made disturbances can affect the whale's delicate balance, and that these disturbances increase nitrogen uptake or cause the whales to surface in a way that makes bubbles more likely. For example, man-made sound is used to look for oil and gas hidden in the sea floor. So-called air guns emit a powerful sound signal that penetrates the sea floor and bounces back from different layers of rock and sediment. The returning echo can be used to generate pictures of the sea floor. Another use for sound is to detect objects in the water, such as schools of fish, sunken boats, or submarines. Detection of submarines is important for the military, to prevent these vessels from being able to secretly attack. The devices used to detect submarines are called sonars and the noise from the sonar may affect the behavior and physiology of whales.

To investigate the potential impact of sonar on whales, we developed a mathematical model that uses the diving behavior of whales to estimate the risk that whales will experience gas bubbles when they return to the surface [4]. An electronic instrument was attached to the whale's skin by suction cups, and this tag recorded the behavior of the whales along with the pressure of the surrounding water (Figure 2). The pressure increases with the water depth. At the surface, the pressure is 1 Atmosphere Absolute (ATA), one of many units to measure pressure. For every $10 \mathrm{~m}$ of depth, the pressure increases by 1 ATA, and by measuring the pressure these instruments were able to record the depth to which the whales were diving while foraging, or hunting for food. We used the pressure data and the Gas Solubility to estimate the amount of gas the whales had dissolved in the blood and tissue, and these estimates gave us an idea of how likely the whales were to experience gas bubbles $[4,5]$. We compared these estimated values of dissolved gas based upon the whales' diving behavior before, during, and after exposure to sonar. The levels of sonar in these experiments were carefully selected to avoid potential damage to the whales, but were high enough to see if the whales responded. For example, if the whales considered the sonar to be a danger, they might rapidly swim 


\section{FIGURE 2}

Dive computers were attached with suction cups to four different types of whales: A. killer whale, B. pilot whale, C. sperm whale, and $\mathbf{D}$. Cuvier's beaked whale. The dive computers recorded the depth of the diving whales. In each graph, time is shown in hours and the dive depth is shown in meters. The black line shows the depth profile of the diving whale, which allows us to count the number of dives and their depth. Notice the big differences in the number of dives and the dive depth between the different whale species. The killer whale $\mathbf{A}$. performed many short and relatively shallow (less than $200 \mathrm{~m}$ ) dives, while the pilot whale $\mathbf{B}$. made rapid deep dives that were still quite short. The sperm whale C. and Cuvier's beaked whale D., on the other hand, made very long and deep dives. The differences in dive behavior were used to determine the differences in the risk of decompression sickness and bubble formation between species (figure reproduced from Ref. [4]). Photo credits: For the killer whale, pilot whale and sperm whale the photographer was Sanna Kuningas/SMRU, the photographer for the Cuvier's beaked whale was Todd Pusser.
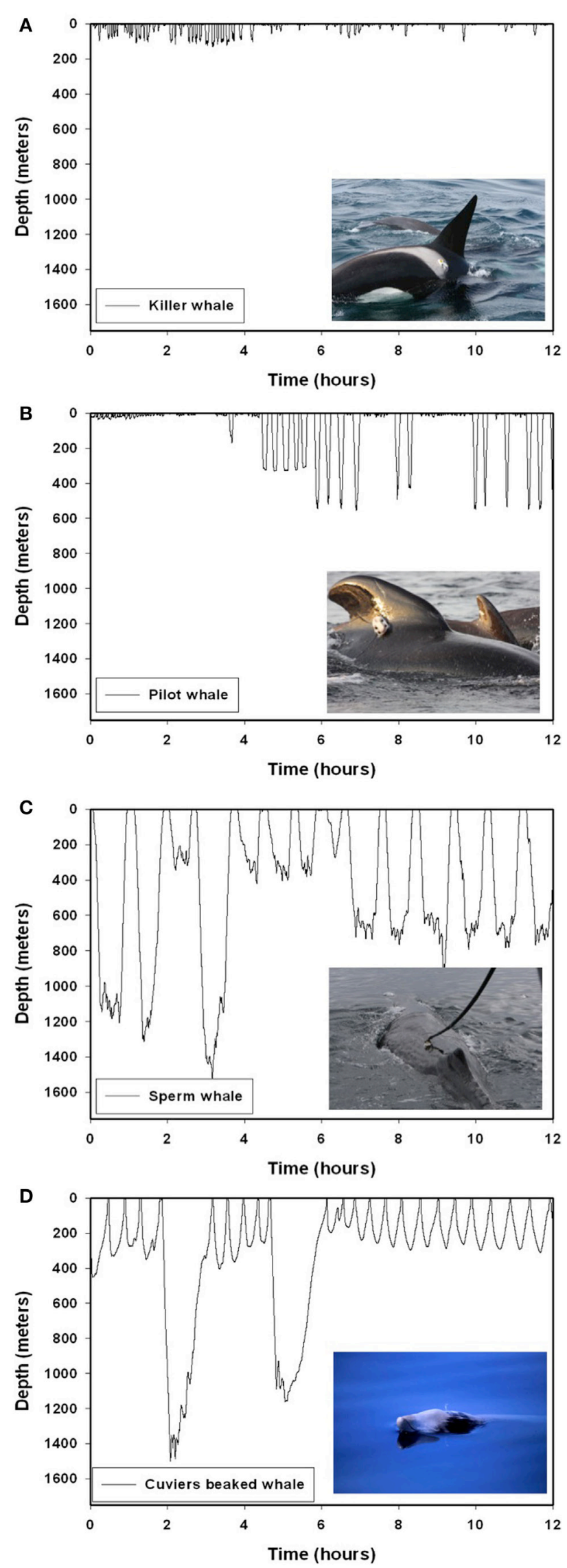

FIGURE 2 
away, or break off a dive and return to the surface before finishing the hunt for food, or in some cases even dive deeper than they normally do [6, 7]. The model considered how these behaviors of the whales could affect the chances that bubbles formed. We concluded that whales that do not regularly dive very deep (like killer whales, Figure $2 \mathrm{~A}$ ) are not likely to increase risk of bubble formation in their body because of sonar, but whales that regularly dive very deep (like sperm whales and beaked whales, Figures 2C,D) may be more prone to bubbles forming during changes in behavior caused by exposure to sonar sound. The results also suggested that if whales increase their physical activity when they are trying to avoid the sonar, this could also increase the risk of bubbles forming (Figure 3).

In our study, we show how man-made noise may alter the risk of bubble formation in shallow- and deep-diving whales. While we currently do not fully understand how these wonderful giants are capable of holding their breath, and diving to enormous depths without the problems that human divers would encounter, our results suggest that there are certain factors that increase the risk of gas bubbles following a dive. For example, larger animals or those that dive deeper may be at higher risk of experiencing gas bubbles. These results are important to help us understand which species

\section{FIGURE 3}

When are whales at risk of forming nitrogen bubbles? The figure shows a whale leaving and returning to the surface during a dive.

The dots show the dive

path as the whale dives to depth to capture the giant squid. At shallow depths, nitrogen is removed from the blood of the whale, but this is also the region where bubbles can form. At intermediate depths, nitrogen is taken up and dissolved in the blood and tissues. In the deep region, the lungs have collapsed as the pressure is compressing the gas. For this reason, no additional gas is taken up and the gas that was taken up in the intermediate region is now circulating between the blood and tissues (figure reproduced from Ref. [5]).

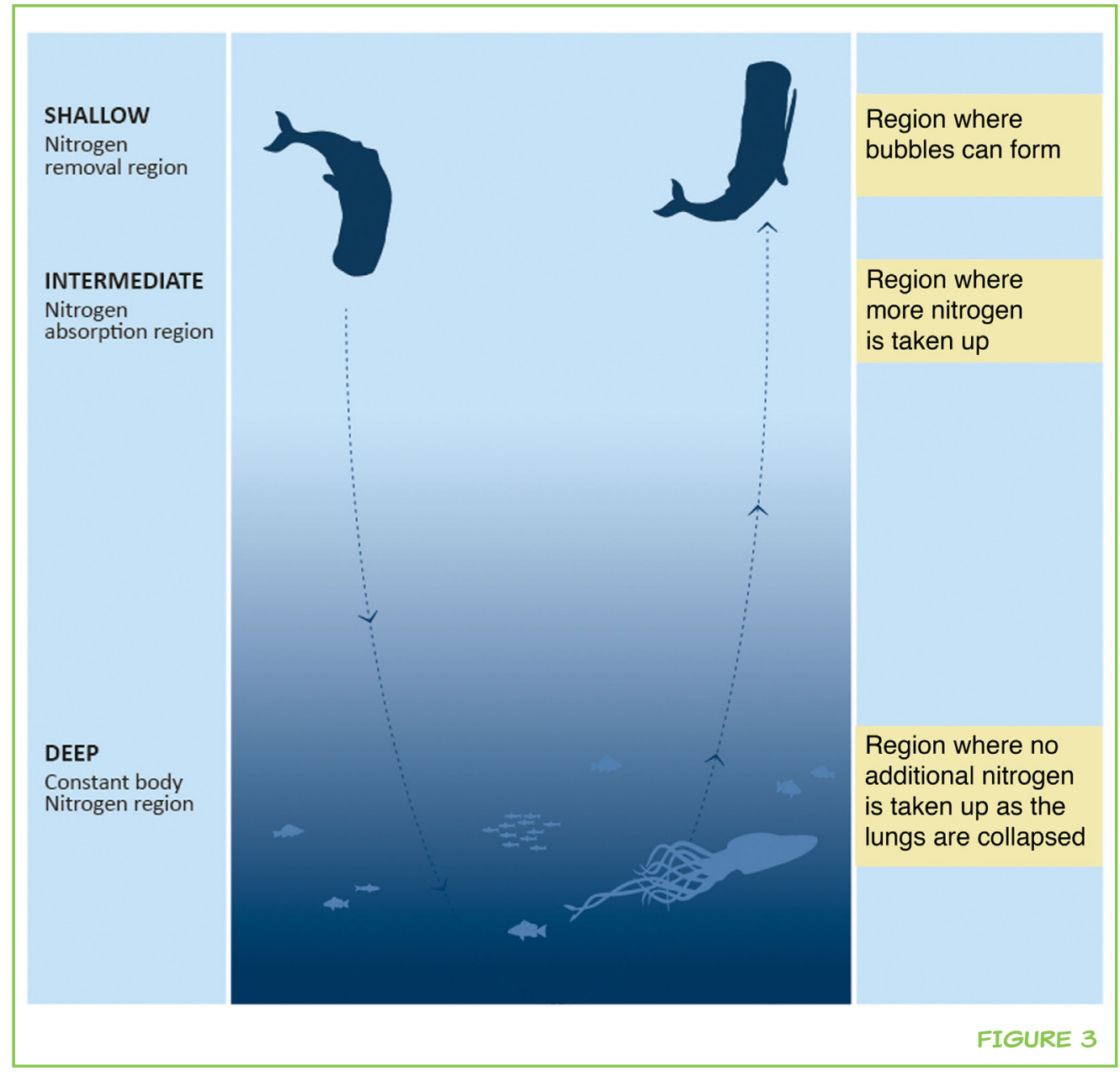


may be at higher risk of forming bubbles. Such information can help government agencies that control where and how sound can be used in the ocean to look for submarines or to search for oil and gas. Consequently, the results we present may be able to help reduce distress in whales and minimize impact from human presence in the ocean. There are still many mysteries to solve about the lives of marine mammals and whales, and often we realize that we have more questions than answers, which is often the case in research.

\section{ORIGINAL SOURCE ARTICLE}

Kvadsheim, P. H., Miller, P. J. O., Tyack, P. L., Sivle, L. L. D., Lam, F.-P. A., and Fahlman, A. 2012. Estimated tissue and blood N2 levels and risk of in vivo bubble formation in deep-, intermediate- and shallow-diving toothed whales during exposure to naval sonar. Front. Physiol. 3:125. doi:10.3389/fphys.2012.00125

\section{REFERENCES}

1. Mahon, R. T., and Regis, D. P. 2014. Decompression and decompression sickness. Compr. Physiol. 4, 1157-1175. doi:10.1002/cphy.c130039

2. Fernandez, A., Edwards, J. F., Rodruiquez, F., Espinosa de los Monteros, A., Herraez, M. P., Castro, P., et al. 2005. "Gas and fat embolic syndrome" involving a mass stranding of beaked whales (Family Ziphiidae) exposed to anthropogenic sonar signals. Vet. Pathol. 42, 446-457. doi:10.1354/vp.42-4-446

3. García-Párraga, D., Crespo-Picazo, J. L., Bernaldo de Quirós, Y., Cervera, V., Martí-Bonmati, L., Díaz-Delgado, J., et al. 2014. Decompression sickness ("the bends") in sea turtles. Dis. Aquat. Org. 111, 191-205. doi:10.3354/dao02790

4. Kvadsheim, P. H., Miller, P. J. O., Tyack, P. L., Sivle, L. L. D., Lam, F.-P. A., and Fahlman, A. 2012. Estimated tissue and blood N2 levels and risk of in vivo bubble formation in deep-, intermediate- and shallow-diving toothed whales during exposure to naval sonar. Front. Physiol. 3:125. doi:10.3389/fphys.2012.00125

5. Fahlman, A., Tyack, P. L., Miller, P. J., and Kvadsheim, P. H. 2014. How man-made interference might cause gas bubble emboli in deep diving whales. Front. Physiol. 5:13. doi:10.3389/fphys.2014.00013

6. Schorr, G. S., Falcone, E. A., Moretti, D. J., and Andrews, R. D. 2014. First longterm behavioral records from Cuvier's beaked whales (Ziphius cavirostris) reveal record-breaking dives. PLoS ONE 9:e92633. doi:10.1371/journal.pone.0092633

7. Miller, P. J. O., Kvadsheim, P. H., Lam, F. P. A., Tyack, P. L., Curé, C., DeRuiter, S. L., et al. 2015. First indications that northern bottlenose whales are sensitive to behavioural disturbance from anthropogenic noise. R. Soc. Open Sci. 2, 140484. doi:10.1098/rsos.140484 
SUBMITTED: 07 April 2017; ACCEPTED: 10 November 2017;

PUBLISHED ONLINE: 18 December 2017.

EDITED BY: Michele A. Johnson, Trinity University, United States

CITATION: Fahlman A, Tyack PL, Miller PJM, and Kvadsheim PH (2017) Human

Disturbances Might Cause Dangerous Gas Bubbles to Form in Deep-Diving Whales. Front.

Young Minds 5:62. doi:10.3389/frym.2017.00062

CONFLICT OF INTEREST STATEMENT: The authors declare that the research was conducted in the absence of any commercial or financial relationships that could be construed as a potential conflict of interest.

COPYRIGHT @ 2017 Fahlman, Tyack, Miller and Kvadsheim. This is an open-access article distributed under the terms of the Creative Commons Attribution License (CC BY). The use, distribution or reproduction in other forums is permitted, provided the original author(s) or licensor are credited and that the original publication in this journal is cited, in accordance with accepted academic practice. No use, distribution or reproduction is permitted which does not comply with these terms.

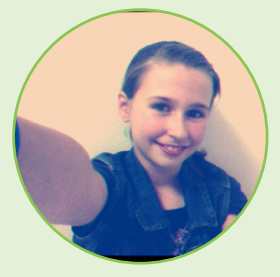

\section{REVIEWED BY}

\section{NADYA, AGE: 12}

I am in seventh grade and live in Seoul, South Korea. My hobbies are playing violin and ukulele, singing, drawing, reading, walking dogs, and watching cartoons. I live with my mom, my dad, and my little brother. I enjoy doing reading and research on marine mammals, especially manatees. I care very much about the environment and how people treat animals. My dream job is to be an actress or singer.

\section{CAROLYN, AGE: 12}

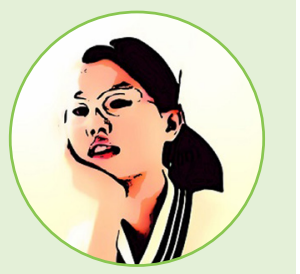

I like to draw, read, write creatively, and learn about wild animals, especially birds and mammals. I am interested in space science, too. My favorite TV show is <Wild Kratts>. The vivid photos and cool facts about animals in DK Eyewitness books have always fascinated me. During my family trip last summer, I encountered a bear, an owl, a seal, a deer, and elephant seals. When I grow up, I want to become an author-illustrator or a zoologist.

\section{AUTHORS}

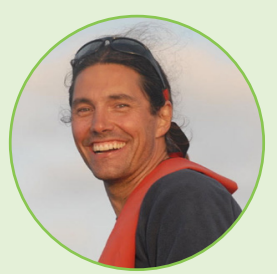

\section{ANDREAS FAHLMAN}

I am working as a comparative physiologist, which means I study different animals and how they survive in different environments. I have been in a wide variety of studies, ranging from deep diving animals and humans to hibernating squirrels. In the past 15 years, I have studied how animals can hold their breath for over $2 \mathrm{~h}$ and dive to a depth of 3 km. *afahlman@oceanografic.org 


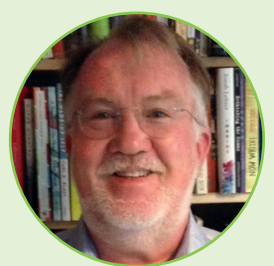

\section{PETER LLOYD TYACK}

Peter Tyack is a Professor of Marine Mammal Biology at the University of St Andrews. His research focuses on behavioral ecology, especially acoustic communication and social behavior in marine mammals. He has studied reproductive advertisement in baleen whales, individually distinctive contact calls, and echolocation in deep diving toothed whales. He has developed new methods to sample behavior continuously from marine mammals, including the development of sound-and-orientation recording tags, and has used these to study communication and echolocation. He has developed a series of studies on responses to anthropogenic sounds, including effects of oil exploration on baleen and sperm whales, and the effects of naval sonar on toothed whales.

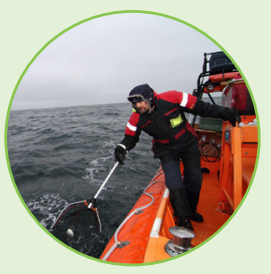

\section{PATRICK JAMES O'MALLEY MILLER}

Patrick is a professor of Biology in the Sea Mammal Research Unit at the University of St. Andrews in Scotland. Working as part of a team studying bird-song at the University of Washington, Patrick was inspired to study animal communication which led to his PhD research on the structure and function of sounds of killer whales. Patrick's research now focuses on marine mammal ecology and behavior, the advancement of new methods like tagging tools and techniques, and understanding how increasing levels of underwater noise produced by humans might affect these animals in their natural environment.

\section{PETTER H. KVADSHEIM}

Petter H. Kvadsheim earned his PhD in zoophysiology from the University of Tromsø, Norway in 1998. His recent interest has been research on the interaction between physiological and behavioral adaptations in marine mammals and on how they respond to anthropogenic disturbances. Dr. Kvadsheim is currently employed at the Norwegian Defence Research Establishment. 